\title{
A Module of Multifactor-Mediated Dysfunction Guides the Molecular Typing of Coronary Heart Disease
}

\author{
Tucheng Huang${ }^{1}$, Yuewei $\mathrm{Li}^{1}$, Maohuan $\mathrm{Lin}^{1}$, Kangjie Wang ${ }^{2}$, Wenli Gu${ }^{1}$, Guanghao Gao ${ }^{1}$, \\ Yuna Huang ${ }^{1}$, Yangxin Chen ${ }^{1}$, Huiying Zhao ${ }^{3}$, and Jingfeng Wang ${ }^{3}$ \\ ${ }^{1}$ Sun Yat-Sen Memorial Hospital \\ ${ }^{2}$ Sun Yat-sen University First Affiliated Hospital \\ ${ }^{3}$ Sun Yat-Sen University
}

May 5, 2020

\begin{abstract}
Molecular typing results are not routinely used for CHD. Aiming to uncover the underlying molecular features for different types of CHD, we screened the differentially expressed genes (DEGs) associated with CHD based on the GEO data and expanded in the NCBI-gene and OMIM databases to finally obtain 2021 DEGs. Then the weighted gene co-expression analysis (WGCNA) was performed on the candidate genes, and 6 distinctive WGCNA modules were identified, 2 of which were associated with CHD. Moreover, DEGs were mined as key genes for co-expression based on the module network relationship. Furthermore, the differential miRNAs of CHD and interactions in the database were mined in the GEO dataset to build a multi-factor regulatory network of key genes for co-expression. Combined these results, the CHD samples were further classified into 5 clusters by using the module core genes, and we defined FTH1, HCAR3, RGS2, S100A9 and TYROBP 5 genes in different subgroups. Finally, FTH1, S100A9 and TYROBP were significantly increased while HCAR3 decreased in mRNA level in CHD patients' blood where RGS2 was hardly determined. In conclusion, the screened core clusters of genes may be potential target for diagnosis and treatment of CHD as a molecular typing module.
\end{abstract}

\section{Hosted file}

manuscript.doc available at https://authorea.com/users/302553/articles/432675-a-module-ofmultifactor-mediated-dysfunction-guides-the-molecular-typing-of-coronary-heart-disease

\section{Hosted file}

Figure 1.tif available at https://authorea.com/users/302553/articles/432675-a-module-ofmultifactor-mediated-dysfunction-guides-the-molecular-typing-of-coronary-heart-disease

\section{Hosted file}

Figure 2.tiff available at https://authorea.com/users/302553/articles/432675-a-module-ofmultifactor-mediated-dysfunction-guides-the-molecular-typing-of-coronary-heart-disease

\section{Hosted file}

Figure 3.tiff available at https://authorea.com/users/302553/articles/432675-a-module-ofmultifactor-mediated-dysfunction-guides-the-molecular-typing-of-coronary-heart-disease

\section{Hosted file}

Figure 4.tif available at https://authorea.com/users/302553/articles/432675-a-module-ofmultifactor-mediated-dysfunction-guides-the-molecular-typing-of-coronary-heart-disease 


\section{Hosted file}

Figure 5.tif available at https://authorea.com/users/302553/articles/432675-a-module-ofmultifactor-mediated-dysfunction-guides-the-molecular-typing-of-coronary-heart-disease

\section{Hosted file}

Figure 6.tif available at https://authorea.com/users/302553/articles/432675-a-module-ofmultifactor-mediated-dysfunction-guides-the-molecular-typing-of-coronary-heart-disease

\section{Hosted file}

Figure 7.tif available at https://authorea.com/users/302553/articles/432675-a-module-ofmultifactor-mediated-dysfunction-guides-the-molecular-typing-of-coronary-heart-disease

\section{Hosted file}

Figure 8.tiff available at https://authorea.com/users/302553/articles/432675-a-module-ofmultifactor-mediated-dysfunction-guides-the-molecular-typing-of-coronary-heart-disease

\section{Hosted file}

Figure 9.tiff available at https://authorea.com/users/302553/articles/432675-a-module-ofmultifactor-mediated-dysfunction-guides-the-molecular-typing-of-coronary-heart-disease

\section{Hosted file}

Figure 10.tif available at https://authorea.com/users/302553/articles/432675-a-module-ofmultifactor-mediated-dysfunction-guides-the-molecular-typing-of-coronary-heart-disease

\section{Hosted file}

Figure 11.tif available at https://authorea.com/users/302553/articles/432675-a-module-ofmultifactor-mediated-dysfunction-guides-the-molecular-typing-of-coronary-heart-disease

\section{Hosted file}

Figure 12.tif available at https://authorea.com/users/302553/articles/432675-a-module-ofmultifactor-mediated-dysfunction-guides-the-molecular-typing-of-coronary-heart-disease

\section{Hosted file}

Figure 13.tif available at https://authorea.com/users/302553/articles/432675-a-module-ofmultifactor-mediated-dysfunction-guides-the-molecular-typing-of-coronary-heart-disease

\section{Hosted file}

Figure 14.tif available at https://authorea.com/users/302553/articles/432675-a-module-ofmultifactor-mediated-dysfunction-guides-the-molecular-typing-of-coronary-heart-disease 